\title{
Chemical Pricing Information for Student Design Projects and Cost Engi- neering: Challenges and Opportunities
}

\section{Mr. David E. Hubbard, Texas A\&M University}

David E. Hubbard is an Associate Professor and Science \& Engineering Librarian at Texas A\&M University Libraries. He received his master's in library science from the University of Missouri-Columbia (2003) and bachelor's in chemistry from the University of Missouri-St. Louis (1988). More recently, he completed a master's in geographic information science from Northwest Missouri State University (2012). Prior to joining Texas A\&M University, he served as the subject liaison to several science and engineering departments at both Texas Tech University and Missouri University of Science \& Technology. 


\title{
Chemical Pricing Information for Student Design Projects and Cost Engineering: Challenges and Opportunities
}

\begin{abstract}
Chemical prices are an important component of cost engineering for chemical engineering students and researchers, as well as other disciplines that might be interested in chemical processes (e.g., agricultural engineering, business, economics, and industrial engineering). Students in chemical engineering senior design (or capstone) courses are especially in need of chemical pricing to demonstrate the economic feasibility of their process designs. Over the last 12 years, bulk chemical prices have become increasingly difficult to locate as information providers publishing such information have consolidated and gradually removed that content from their publications. This paper first summarizes the history of published chemical prices in the literature and then reports on a quantitative content analysis of library research guides containing chemical pricing sources at institutions with ABET-accredited chemical engineering programs. Despite the aforementioned challenges, there are some opportunities for engineering librarians. One such opportunity involves locating citations for chemical prices from a variety of sources and placing them into a searchable database that could be a community-based solution.
\end{abstract}

\section{Introduction}

Obtaining chemical pricing information is essential for performing cost analyses in the chemical process industry. It is not only important to practicing engineers, but also chemical engineering students working on design projects and researchers performing techno-economic analyses on new or existing chemical processes. Finding chemical pricing information has always been challenging, but recent industry consolidation of the companies providing chemical pricing information and monetization of such information over the last 12 years has made it even more challenging. There are a limited, disparate number of sources for chemical pricing information. This has been true historically and even more so today. The objectives of this study are to identify and characterize chemical pricing information found on library research guides through a quantitative content analysis, as well as make a modest proposal for the creation of a "crowdsourced" chemical pricing database.

\section{Literature Review and Background}

Before discussing the study and its results, some background information is needed. The following section discusses the history of chemical pricing, selected sources for chemical pricing information, chemical price indices, and research guides.

History

Some of the earliest surviving published prices of goods in the Western world emerged during the late sixteenth century in major trading cities like Amsterdam, Frankfurt, Hamburg, and Venice, and then spread throughout Europe, and ultimately to the United States via England. ${ }^{1-3}$ These publications, referred to as price-currents, listed market prices for various goods that included many agricultural products and a limited number of chemicals, such as potash, saltpeter, sulfur, etc. ${ }^{3,4}$ One of the first price-currents published in colonial America was the South Carolina Price-Current and it included chemicals such as indigo, turpentine, and various animal/plant oils. ${ }^{1,5}$ Price-currents continued into the early 1800 s and then developed into, or 
were displaced by, specialized financial newspapers or trade magazines that often included pricing. ${ }^{1}$ Some of the earliest trade magazines focusing on chemistry and chemical processes included The Chemical Record and Drug Price Current (1851), American Druggists' Circular and Chemical Gazette (1855), and the Oil, Paint, and Drug Reporter (1871). The latter became, and continues to be, one of the more important and accessible sources for commodity chemical prices for academic institutions. In 1972 the Oil, Paint, and Drug Reporter changed its name to Chemical Marketing Reporter and then to Chemical Market Reporter in 1996. In 2000 the publisher of the Chemical Market Reporter, Schnell Publishing, was acquired by Reed Business Information and the title of the Chemical Market Reporter was changed to ICIS Chemical Business in 2006. ${ }^{6}$

Professional societies and trade associations, like the American Chemical Society and Manufacturing Chemists Association (now American Chemical Council), published chemical pricing information in Chemical \& Engineering News and Chemical Statistics Handbook, respectively. Chemical pricing ceased to be published in Chemical \& Engineering News in the 1950s and the Chemical Statistics Handbook ceased in 1971. Both the American Chemical Society and the American Chemical Council still publish useful economic information related to chemical manufacturing (e.g., production/consumption data), just not individual chemical prices.

Companies specializing in chemical pricing and related information services began to emerge in the second half of the twentieth century. Initially developed by Stanford Research Institute (SRI) International in 1950, the Chemical Economics Handbook (CEH) now contains reports with information on supply/demand, manufacturing processes, and prices for over 300 chemicals. ${ }^{7,8} \mathrm{~A}$ small number of academic libraries purchased the print loose-leaf early on, but CEH was mainly marketed to industry and priced accordingly. IHS acquired SRI Consulting in 2010, which included the CEH. Now available online, cost and licensing terms resulted in only a small number of academic libraries acquiring the $\mathrm{CEH}$. Another major commercial entity in the chemical pricing marketplace is ICIS (originally Independent Chemical Information Services and now a division of Reed Business Information), publisher of ICIS Chemical Business, chemical price reports, and related products and services. ${ }^{9,10}$

\section{Bulk versus Laboratory Chemical Pricing}

Bulk (or commodity) chemicals are those that are produced and purchased in large quantities, usually in tons. It is important to note the prices paid for laboratory quantities (gram or kilogram) are substantially different from those paid for bulk amounts (tons) needed for industrial processes. One cannot use a price for laboratory quantity to calculate a realistic price for a bulk quantity. For example Spectrum Chemical, a laboratory chemical supplier that sells rather large packaged amounts, sells a 55-gallon drum of ethylene glycol for $\$ 2,235$ (or $\$ 4.43 / 1 \mathrm{~b}$ ); whereas a recent published bulk price in ICIS Chemical Business is $\$ 0.38 / \mathrm{lb}$ or $\$ 760 /$ ton. ${ }^{11,12}$ Calculating the price for one ton based on $\$ 4.43 / \mathrm{lb}$ from Spectrum Chemical would yield a price of $\$ 8,860 /$ ton! These values differ by more than an order of magnitude. Understanding that prices paid for laboratory quantities cannot just be scaled to bulk quantities is an important concept and something that should be communicated when describing chemical pricing sources, especially if sources for both bulk and laboratory chemical pricing are listed together. 


\section{Sources for Chemical Pricing}

While some of the more recent monographs outlining engineering information resources list the Chemical Market Reporter (now ICIS Chemical Business) along with other chemical engineering trade magazines (e.g., Chemical Engineering, Chemical Week, etc.), ${ }^{13,14}$ there is not much discussion about those trade magazines in terms of chemical pricing or mention of other sources. Two of the more recent publications to discuss sources of chemical pricing are How to Find Chemical Information ${ }^{8}$ and A Brief Guide To Finding Chemical and Petroleum Prices and Other Statistical Information. ${ }^{15}$ Some of the bulk chemical pricing sources mentioned by Maizell ${ }^{8}$ and Reichardt ${ }^{15}$ remain relevant: Chemical Economics Handbook, Chemical Market Reporter (now ICIS Chemical Business), USGS Mineral Commodity Summaries, and U.S. Energy Information Administration [Petroleum \& Other Liquids]. The first two sources have already been discussed; the other two are U.S. government sources that provide pricing and other economic information. Energy Information Administration [Petroleum \& Other Liquids] provides prices for petroleum related products (crude oil, gasoline, diesel, and propane) and the USGS National Minerals Information Center [Mineral Commodity Summaries] provides prices for some inorganic chemicals (e.g., ammonia, sulfur, titanium dioxide, etc.).

Discussion of chemical prices in this paper, and almost everywhere else, are referring to spot prices (or current market prices). The spot price is an average and may not be representative for an entire geographic location (e.g., a particular region within a country). It should also be noted that it is not unusual for buyers to enter into long-term contracts with chemical producers and pay less than the spot price. The most accurate pricing would be a direct quote from chemical manufacturers, ${ }^{8,16}$ but chemical manufacturers may be reluctant to provide such information to those not actually seeking to purchase chemicals (e.g., students working on capstone projects or researchers working on techno-economic analyses). In those situations, one turns to the published literature and related sources.

The sources (trade magazines, pricing services, market reports, and government websites) and providers (commercial, governmental, and trade associations) of chemical pricing information are quite varied. It is also constantly changing and commercial sources have been moving towards greater consolidation over the last 12 years. ${ }^{17,18}$ Two companies, IHS Markit and Reed Business Information, have acquired a number of the businesses that provide chemical pricing information. As the industry consolidated through acquisitions, much of the chemical pricing was removed and further monetized through additional pricing services and reports. This is indeed the case for two of the most accessible sources for students and academics: Chemical Market Reporter and Chemical Week. The Chemical Market Reporter listed bulk chemical pricing for 100s of chemicals on a weekly basis, but most chemical pricing was removed after the March 21, 2005 issue, ${ }^{19}$ though ICIS later created a student webpage providing historical pricing (ICIS Indicative Chemical Prices) containing chemical prices from the 2006-2008 timeframe. ${ }^{19,20}$ ICIS Chemical Business (formerly Chemical Market Reporter) still carries a 1page section titled "Chemical Profiles" that provides information on chemical pricing, production, and technology for an individual chemical. Chemical pricing can also be found in the Price and Market Trends section of ICIS Chemical Business. Until early 2010, Chemical Week published weekly pricing for approximately 20 major commodity chemicals in a section titled "CW Price Report" and a "Product Focus" section that was very similar to the ICIS Chemical Business Chemical Profiles. Despite those sections being removed, Chemical Week still contains 
some chemical pricing for individual chemicals in a section titled "Basic Chemicals \& Plastics." Unfortunately access to these two trade magazines, Chemical Market Reporter and Chemical Week, has become more difficult for academic libraries. ICIS Chemical Business ceased print publication in January 2017 and is now only available online, though the access requires an individual username and password that cannot be shared and is not a licensing term most academic libraries can agree to. As of this writing, access is still available through EBSCO's Business Source Complete and ProQuest's ABI/INFORM. Chemical Week is still available in print and online as separate subscriptions from the publisher, but access through aggregators like EBSCO and ProQuest ceased in 2010 and 2012, respectively. To assist with locating pricing information in these two trade magazines, Texas A\&M University and University of Texas, have created finding aids for chemicals prices published in Chemical Week and ICIS Chemical Business, respectively.

Chemical Price Indices

It should be mentioned that there are producer price indices that can be used to adjust an older chemical price to estimate current prices. The basic cost index formula is as follows:

$$
\text { New Price }=\text { Older Price } x \frac{(\text { Cost Index at Date2) }}{(\text { Cost Index at Date1) }}
$$

Where: Date $1=$ Date when the older price was obtained

Date2 $=$ Current Date (or Date of Value for the Cost Index)

The Bureau of Labor Statistics (BLS) publishes a large number of producer price indices (PPI), including cost indices for "Chemicals and Allied Products" and "Industrial Chemicals." ${ }^{21}$ In addition to those general cost indices, there are cost indices for various classes of chemicals (Inorganic Chemicals, Organic Chemicals, Industrial Gases, etc.) and even some costs indices for individual chemicals (e.g., carbon black, oxygen, sulfuric acid, etc.). ${ }^{22}$ Caution should be taken with aggregated indices (e.g., Organic Chemicals), especially if adjusting over long time periods since the chemicals comprising that index may change over time. Unlike chemical equipment or plants where it is recommended to limit price adjustments to no more than 10 years,,${ }^{16,23}$ no such limitation exists for the BLS's producer price indices with the exception of the aggregated indices just mentioned (BLS Personal Communication, January 29, 2018). The BLS PPIs are based on actual prices received by chemical producers and therefore have factored in supply/demand, technological improvements, etc. in the price index. ${ }^{21}$ Additional information about using cost indices in chemical engineering processes can be found in El-Halwagi ${ }^{23}$ and Peters et al. ${ }^{16}$

\section{Research Guides}

Research guides, library webpages listing information sources for a particular subject or class assignment, emerged in the mid-1990s and it was rare to find a library without research guides by the mid-2000s. ${ }^{24}$ The platforms used to host content on research guides has changed over the years, but LibGuides is the primary software used by academic libraries for research guides. ${ }^{24} \mathrm{As}$ mentioned in the previous sections, there are no recent articles on sources for chemical pricing information and the information landscape is ever changing with respect to access and content. Even if there were recent published lists of sources, it would not necessarily indicate what 
librarians are actually recommending to patrons or the context. Content analysis, a research technique used to make "replicable and valid inferences from texts...to the contexts of their use" (p. 24), ${ }^{25}$ has been used to analyze research guides for content and organization in engineering ${ }^{26,27}$ and other disciplines. ${ }^{28-33}$ Such studies can help identify what sources and tools librarians are currently recommending to patrons and how their research guides are organized. To date, no study has performed such an analysis on chemical pricing research guides.

\section{Objectives and Questions}

The main objectives of this study is to quantify and characterize sources listed on library chemical pricing research guides at institutions with ABET-accredited programs in chemical engineering. It also examines whether a distinction between bulk and laboratory pricing sources is made, and if producer price indices on the research guides are present. More specifically, this study seeks to determine:

1. What is the prevalence of chemical pricing research guides among academic libraries and institutions with ABET-accredited chemical engineering programs?

2. What sources, individually and categorically, are listed on the chemical pricing research guides?

3. If the chemical pricing research guide contains sources for laboratory pricing, is a distinction made between bulk and laboratory pricing sources? If so, how?

4. Are producer price indices present on library chemical pricing research guides and are they described in a manner that clearly states their purpose and use?

\section{Methods}

Chemical Pricing Sources

The library research guides of the 157 institutions offering ABET-accredited chemical engineering degrees were reviewed and the names of chemical pricing sources listed were compiled. ${ }^{34}$ This was accomplished by visiting each library website and checking the chemical engineering and chemistry research guides. If possible, as in the case of LibGuides, all research guides at that library were searched using the terms "chemical prices" and "chemical pricing." If more than one research guide existed at an institution, subject guides (e.g., chemical engineering or chemistry) were selected over class guides or in cases of two subject/two class guides the one with the largest number of sources was selected. If a research guide contained chemical pricing sources, the names of the sources were recorded, compiled, and categorized. The name and type of guide (chemical engineering, chemistry, class, etc.) was noted, as was the location of the chemical pricing sources (individual/separate page, tab, or section). More specifically, was it a separate chemical pricing guide (page), a tab within a larger guide (tab), or a section on a 1-page guide or within tabbed section (section).

In addition to the sources and their location, two other items were noted when reviewing each research guide. The first is whether there was a distinction made between bulk and laboratory chemical pricing. If sources for laboratory chemical pricing were listed (e.g., laboratory chemical buyers catalogs, etc.), did the research guide communicate that such pricing differs significantly from bulk pricing and how that was communicated. For this study, sources like eMolecules, Reaxys, SciFinder, and Sigma-Aldrich are considered laboratory chemical pricing sources. The second was the presence of producer price indices for adjusting older prices to the present, as 
well as an accompanying description regarding their purpose and use. The findings were recorded, tabulated, and managed in an Excel spreadsheet.

\section{Results}

Overview

Of the 157 institutions offering ABET-accredited chemical engineering degrees, 48 (31\%) of the libraries associated with those institutions had a research guide with chemical pricing. The number of sources listed on the chemical pricing research guide ranged from 1 to 32, with a mean of 10 and a median of 8 . Collectively, there were 140 different sources listed on the 48 research guides.

\section{Research Guide Location}

Table 1 summarizes the type of research guides (i.e., independent guide, subject guide, or class guide) and the name of that research guide where the chemical pricing information resided. Over half $(63 \%)$ of the research guides were on a chemical engineering subject or class guides.

Table 1. Summary of Research Guide Types

\begin{tabular}{|l|l|c|}
\hline Type of Guide & Subject/Name of the Guide & Count \\
\hline Subject Guide & Chemical Engineering $^{1}$ & 21 \\
\hline Class Guide & Chemical Engineering $^{1}$ & 9 \\
\hline Subject Guide & Chemistry & 9 \\
\hline Independent Guide & Chemical Pricing & 6 \\
\hline Subject Guide & Combined Chemistry and Chemical Engineering Guides & 2 \\
\hline Subject Guide & Engineering & 1 \\
\hline
\end{tabular}

${ }^{1}$ Includes "Chemical Engineering" departments with various names (e.g., Chemical \& Biomolecular Engineering)

The 140 sources were categorized into 16 groups and summarized in Table 2. Commercial websites, online chemical product directories, business databases, and trade magazines accounted for over half (55\%) of the source types. Commercial website category was the most varied and included companies that sell chemical pricing information and market reports (e.g., ICIS, IHS, Oil Price Information Service), chemical company websites, and commercial companies posting freely available chemical/material prices (London Metal Exchange, The Plastics Exchange, etc.).

Table 3 summarizes the location of chemical pricing information within the larger research guide (i.e., Page, Tab, or Section) and the names used to label those pages, tabs, or sections containing the chemical pricing information. As noted in Table 1 and shown again in Table 3, there were only six that had research guides dedicated to chemical pricing. The location of the other 42 research guides is fairly evenly divided between Tabs and Sections. Chemical Prices, Finding Chemical Prices and Chemical Pricing were the most common names, followed by a long list. Many of other names listed in Table 3 were variations on Bulk Chemical Price (or Pricing) and Chemical Pricing (or Prices) in conjunction with additional terms. 
Table 2. Types of Sources Listed on Library Chemical Pricing Research Guides

\begin{tabular}{|l|c|l|}
\hline Source Type & Count & \multicolumn{1}{|c|}{ Example } \\
\hline Website - Commercial & 24 & ICIS Indicative Chemical Prices A-Z \\
\hline Website - Product Directory & 20 & ChemExperer.com \\
\hline Database - Business & 18 & Business Source Complete \\
\hline Trade Magazine & 15 & ICIS Chemical Business \\
\hline Website - Government & 11 & USGS National Minerals Information Center \\
\hline Monograph/Encyclopedia & 9 & Kirk-Othmer Encyclopedia of Chemical Technology \\
\hline Website - Library Chem Pricing & 8 & University of Texas \\
\hline Database - Science/Engineering & 7 & SciFinder \\
\hline Vendor Catalog & 7 & Sigma-Aldrich \\
\hline Buyer's Guide & 4 & OPD Chemical Buyers Directory \\
\hline Database - News & 4 & LexisNexis Academic \\
\hline Website - Nonprofit & 4 & International Drug Price Indicator Guide \\
\hline Database - General & 2 & Academic Search Complete \\
\hline Database - Government & 2 & Trade DataWeb (U. S. International Trade Commission) \\
\hline Newspaper - Business & 2 & Financial Times (London) \\
\hline Other & 3 & Miscellaneous Sources (e.g., Local Files) \\
\hline
\end{tabular}

\section{Chemical Pricing Sources}

Table 4 lists the sources present on five or more of research guides examined and a complete listing of sources is shown in Appendix A. Of the 140 sources, 76 sources (or 54\%) were unique to only one research guide.

In tabulating sources, aggregation of similar sources was kept to a minimum to retain the uniqueness of the entries. For example, there are numerous entries for various ICIS webpages (i.e., ICIS Website, ICIS Indicative (or Historical) Pricing, ICIS Price Reports, etc.) that were kept as separate entries. Two exceptions were webpages associated with the U.S. Energy Information Administration and USGS National Minerals Information Center websites, which were all aggregated under those two names.

\section{Bulk versus Laboratory Chemical Pricing}

A number of sources listed in Table 4 are for laboratory quantities (e.g., Sigma-Aldrich, Fisher Scientific, etc.). A question this study sought to examine is whether a distinction is being made between bulk and laboratory pricing sources on research guides, and if so, how that distinction is being made. Of the 48 research guides, 35 (73\%) listed sources that provided laboratory quantities and pricing. Of those 35 with sources for laboratory quantities and pricing, only $12(34 \%)$ made a distinction between bulk and laboratory pricing sources. There were three approaches employed to make that distinction: (1) Provide an introductory statement, (2) Annotate specific sources, and (3) Spatially separate bulk and laboratory sources under different subheadings (Table 5). 
Table 3. Location of the Library Chemical Pricing Content

\begin{tabular}{|c|c|c|c|c|}
\hline Name & Page & Tab & Section & Total Count \\
\hline Chemical Prices & 1 & 7 & 4 & 12 \\
\hline Finding Chemical Prices & & 3 & 1 & 4 \\
\hline Chemical Pricing & & 3 & 2 & 5 \\
\hline Bulk Chemical Prices & & 1 & & 1 \\
\hline Bulk Chemical Pricing and Market Data & & & 1 & 1 \\
\hline Bulk Chemical Pricing Information & & & 1 & 1 \\
\hline Bulk Chemical Pricing Information & & & 1 & 1 \\
\hline Chemical Commodity Prices & & 1 & & 1 \\
\hline Chemical Commodity Prices: Overview & 1 & & & 1 \\
\hline Chemical Economics & & 1 & & 1 \\
\hline Chemical Engineering Economics & & 1 & & 1 \\
\hline Chemical Prices \& Products & & 1 & & 1 \\
\hline Chemical Prices \& Suppliers & 1 & & & 1 \\
\hline Chemical Prices and Pricing & & 1 & & 1 \\
\hline Chemical Prices Sources & & & 1 & 1 \\
\hline Chemical Pricing \& Cost Information & & & 1 & 1 \\
\hline Chemical Pricing \& Suppliers & 1 & & & 1 \\
\hline Chemical Pricing and Sources & 1 & & & 1 \\
\hline Chemical Pricing Information & & 1 & & 1 \\
\hline Chemical Pricing Sources & & & 1 & 1 \\
\hline Chemical Suppliers \& Pricing Information & & & 1 & 1 \\
\hline Commercial Availability Sources & & & 1 & 1 \\
\hline Find CEPCI \& Chem Prices & & 1 & & 1 \\
\hline Find Chemical Prices: Overview & 1 & & & 1 \\
\hline Find Pricing and Industry Information & & & 1 & 1 \\
\hline Finding Chemical Suppliers and Prices & & & 1 & 1 \\
\hline Price & & & 1 & 1 \\
\hline Price Lists \& Buyers' Guides & & & 1 & 1 \\
\hline Pricing & & 1 & & 1 \\
\hline Sources/Pricing & & 1 & & 1 \\
\hline Total Count & 6 & 23 & 19 & 48 \\
\hline
\end{tabular}

\section{Chemical Cost Indices}

As mentioned earlier, producer price indices provide a means for adjusting older chemical prices to the present. Many of the research guides examined listed Chemical Engineering (a trade magazine) for the Chemical Engineering Plant Cost Index (CEPCI), but the cost indices in Chemical Engineering are for chemical plants/equipment and not chemicals. Of the 48 research guides, only five mentioned producer price indices. In the opinion of this author, none of the research guides provided both an appropriate source for chemical price indices and a sufficient 
description of their purpose and use.

Table 4. Summary of Chemical Pricing Sources on Library Research Guides.

\begin{tabular}{|c|c|c|}
\hline Resource Name & Resource Type & Count \\
\hline ICIS Chemical Business & Trade Magazine & 29 \\
\hline ICIS Indicative Chemical Prices A-Z & Website - Commercial & 29 \\
\hline SciFinder & Database - Science/Engineering & 26 \\
\hline Sigma-Aldrich & Vendor Catalog & 24 \\
\hline Chemical Week & Trade Magazine & 19 \\
\hline Business Source Complete & Database - Business & 16 \\
\hline Chemical \& Engineering News & Trade Magazine & 13 \\
\hline USGS National Minerals Information Center & Website - Government & 12 \\
\hline Kirk-Othmer Encyclopedia of Chemical Technology & Monograph/Encyclopedia & 11 \\
\hline U.S. Energy Information Administration & Website - Government & 10 \\
\hline Chemical Profiles/ICIS Chemical Business (U of Texas) & Website - Library Chem Pricing & 9 \\
\hline Factiva & Database - Business & 9 \\
\hline Chem Sources & Buyer's Guide & 8 \\
\hline ChemExper.com & Website - Product Directory & 8 \\
\hline Chemical Engineering & Trade Magazine & 8 \\
\hline ICIS Website & Website - Commercial & 8 \\
\hline LexisNexis Academic & Database - News & 8 \\
\hline ThomasNet & Website - Product Directory & 8 \\
\hline Ullmann's Encyclopedia of Industrial Chemistry & Monograph/Encyclopedia & 8 \\
\hline Chemical Market Reporter & Trade Magazine & 7 \\
\hline ICIS for Students & Website - Commercial & 6 \\
\hline Reaxys & Database - Science/Engineering & 6 \\
\hline ABI/INFORM & Database - Business & 5 \\
\hline Cornell Chemical Pricing Guide & Website - Library Chem Pricing & 5 \\
\hline eMolecules & Website - Product Directory & 5 \\
\hline Fisher Scientific & Vendor Catalog & 5 \\
\hline OPD Chemical Buyers Directory & Buyer's Guide & 5 \\
\hline UT Chemical Economics Guide & Website - Library Chem Pricing & 5 \\
\hline
\end{tabular}

Table 5. Bulk Versus Laboratory Chemical Pricing Distinction

\begin{tabular}{|l|c|c|c|c|c|}
\hline $\begin{array}{c}\text { Lab Sources } \\
\text { Listed }\end{array}$ & Count & $\begin{array}{c}\text { Bulk/Lab } \\
\text { Distinction }\end{array}$ & Intro Statement & Annotations & Spatial Separation \\
\hline No & 13 & N/A & - & - & - \\
\hline Yes & 23 & No & - & - & - \\
\hline Yes & 12 & Yes & 4 & 5 & 3 \\
\hline
\end{tabular}




\section{Discussion}

While not the majority, a sizeable proportion of library research guides at the 157 institutions offering ABET-accredited chemical engineering programs have at least a section with chemical pricing sources. These were often found on a tab or within a section on chemical engineering subject or class guide, and to a lesser extent chemistry subject guides. There were few individual/separate research guides specifically dedicated to chemical pricing.

The presence or absence of certain sources on a research guide is often governed by perceived patron needs and what resources are licensed by the library. If a librarian is not familiar with the need (or has no requests), they are not likely to include such information. Furthermore, libraries may have policies that restrict the types and organization of research guides, leaving little discretion for a librarian to create chemical pricing research guide or even a chemical pricing tab. On the other hand, the presence or absence of chemical pricing guides may just be a reflection of the resources needed and used at a given institution.

Many of the sources mentioned by Maizell ${ }^{8}$ and Reichardt ${ }^{15}$ remain important based on their occurrence on current research guides, though these major sources-many around for decades-represent only a small number of the 140 sources listed on the 48 research guides examined. In addition to some of these traditional sources, a large number of online vendor catalogs and product directories mainly selling laboratory chemicals have been included on many chemical pricing guides. It is interesting to note that a number of library chemical pricing guides link to chemical pricing guides at other libraries. Included among those eight chemical pricing guides are two libraries-Texas A\&M University and the University of Texas-that provide volume/issue information for the Basic Chemicals \& Plastics and Chemical Profiles sections in Chemical Week and ICIS Chemical Business, respectively. Such tools can help students and researchers locate chemical pricing for specific chemicals. On the other hand, such tools may deny students the opportunity to learn about the intricacies of searching and finding chemical pricing. These tools and approaches are a double-edged sword.

It is interesting to note that there was not a single source common to all 48 research guides. The most frequently listed sources, ICIS Chemical Business and ICIS Indicative Chemical Prices, appeared on $29(60 \%)$ of the research guides. The next two most frequently listed sources, SciFinder and Sigma-Aldrich, were common to 26 (54\%) and 24 (50\%) of the research guides, respectively. However, SciFinder and Sigma-Aldrich are sources for laboratory quantities. The remaining 136 sources were on less than half of the research guides and over half of the sources were unique to only one research guide. Two freely available U.S. government chemical pricing sources, U.S. Energy Information Administration and USGS National Minerals Information Center, were on $25 \%$ or fewer of the research guides.

Many of the chemical pricing research guides contained sources for laboratory quantities and prices, but most did not make a distinction between bulk and laboratory pricing differences. In the opinion of this author, this distinction is an important concept for students to understand and a teachable moment lost when no distinction is made. As reported above, this could be addressed by providing an introductory statement, annotating laboratory sources, or separating bulk and laboratory sources using different subheadings. 
Producer price indices are seldom mentioned or described on library chemical pricing research guides. Cost indices are useful tools that can be used to estimate current chemical prices based on older published prices. Given that bulk chemical pricing has become increasingly harder to locate as chemical pricing information is removed and monetized into additional products/services, cost indices provide a viable means to extend existing published chemical prices into the future.

\section{Limitations}

There are several limitations to the study. One is that this study only examined ABET-accredited chemical engineering programs in the United States, so care should be used to extrapolate findings to other institutions. As stated in the methods section, a search for chemical pricing on research guides was conducted using two approaches. Despite systematic and extensive searching, research guides containing chemical pricing sources may have been missed. Among the research guides with chemical pricing, some research guides mingled and blurred sources that are not strictly chemical prices (e.g., production data, suppliers, etc.) under the heading of "chemical pricing." Consequently, some of the sources listed in Table 4 and Appendix A are not necessarily chemical pricing sources, but may be useful for finding suppliers, supply/demand data and other information related to chemical economics and marketing industrial chemicals.

\section{Future Work and a Modest Proposal}

Considering that chemical pricing sources can be quite disparate and that the chemical prices can be buried within those sources, the author decided to create a freely available online database that provides citation information for articles containing bulk chemical pricing for specific chemicals (e.g., Acetone in the Price and Market Trends section of ICIS Chemical Business) or a source title if routinely published in a particular source (e.g., propylene prices in the U.S. Industry Quarterly Review-Chemicals). A beta version of database was deployed on January 31, 2018. At the time of its launch, the hosted web-based solution ${ }^{35}$ contained over 350 citations for chemicals in Chemical Week and ICIS Chemical Business (2016-present) and is accessed through the Texas A\&M University Libraries chemical engineering research guide. ${ }^{36}$ The rationale for a full citation is to facilitate interlibrary loan for users that do not have immediate access to publications listed in the database. The database is searchable by chemical name and Chemical Abstracts Service Registry Number (CASRN). A screenshot of the search interface and a result are shown in Figure 1. In addition to pricing from Chemical Week and ICIS Chemical Business, other sources will be added over time. Some of the entries added may be hard to find chemical pricing from random sources that were "discovered" by a librarian while helping a patron. Such finds can be added to the database so that it doesn't need to be rediscovered later by the author or librarians at other institutions. Librarians at other institutions could also send their finds to the author for inclusion in the chemical pricing database, creating a community resource for the engineering librarian profession and others. Additional "editors" outside of the host institution could be added if additional assistance is needed to manage database submissions. As mentioned above, a tool like this is a double-edged sword in that it can help our students (and librarians) locate chemical pricing and at the same time deny our students an opportunity to learn how to find such information on their own. 


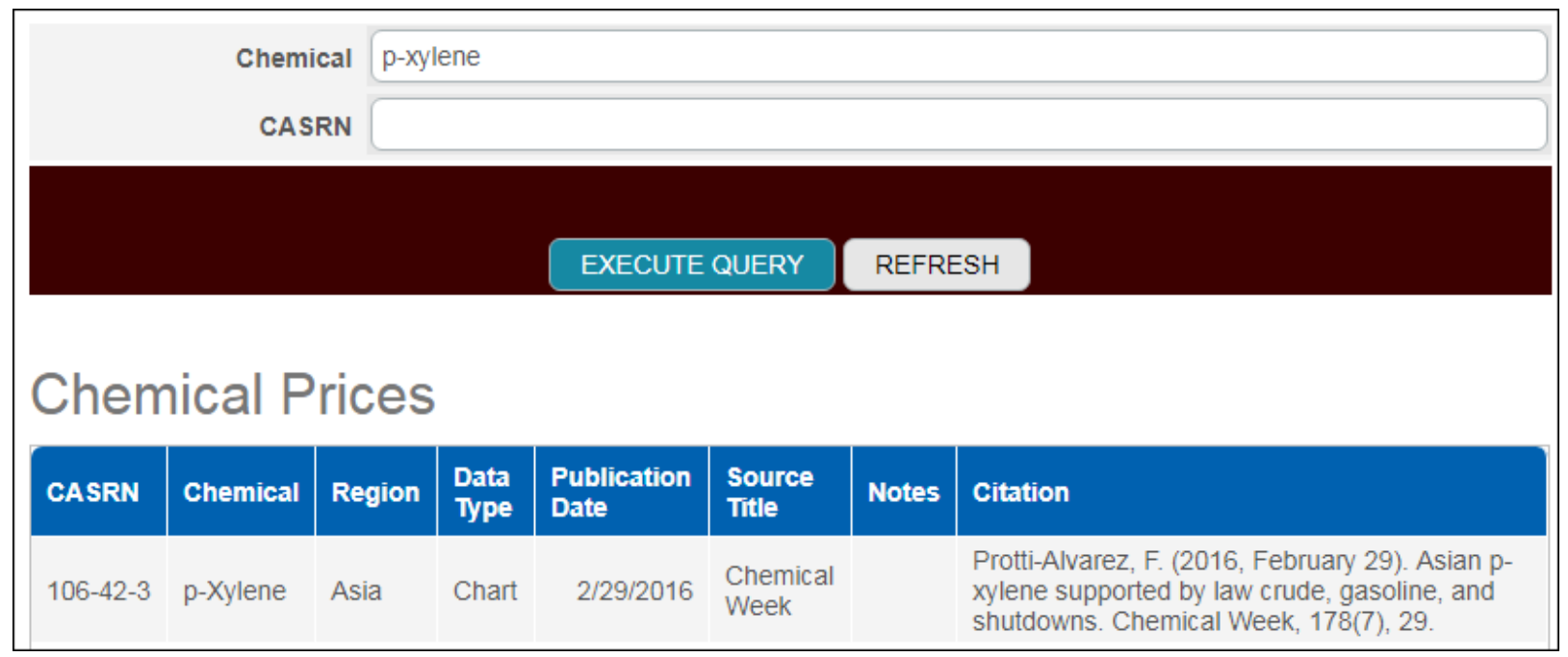

Figure 1. Screenshot of the Chemical Pricing Database Search Result.

\section{Conclusion}

Chemical pricing is an important component for performing chemical engineering cost analyses and it can be difficult information for students and researchers to locate; it is not information that is easily discoverable without some knowledge of sources and search strategies. Consolidation of the chemical pricing information industry has reduced the quantity of chemical pricing available through traditional sources, such as trade magazines, and has made the situation more challenging. To help students locate chemical prices, some libraries have included chemical pricing sources on their research guides. This study determined that $31 \%$ of libraries at institutions with ABET-accredited programs in chemical engineering have research guides with chemical pricing sources. The 140 sources listed by librarians were quite diverse. Only 4 of the 140 sources appeared on $50 \%$ or more of the research guides examined and over half of the sources were unique to a single research guide. In the opinion of this author, many of the chemical pricing research guides do not sufficiently distinguish between bulk and laboratory pricing sources and none really include and describe the use of producer prices indices. Libraries are creating finding aids and tools, such as a chemical pricing database being proposed in this paper, to assist our patrons (and librarians) with locating chemical pricing. It is hoped that the findings of this study will not only help librarians enhanced the sources on their own research guides, but to serve as a catalyst toward the creation of what could be a community-based solution using our collective experience searching for chemical prices.

\section{Acknowledgment}

I would like to thank my graduate student Swati Babbar, Texas A\&M University May's Business School, for assisting with various aspects of reviewing research guides, compiling data, and managing the database.

\section{References}

[1] Bernt, J. (1998). Specialized business publications. In C. J. Burwash (Ed.), History of the mass media in the United States: An encyclopedia. Chicago: Fitzroy Dearborn Publishers.

[2] Forsyth, D. P. (1964). The business press in America. Philadelphia: Chilton Company. 
[3] McCusker, J. J., \& Gravesteijn, C. (1991). The beginnings of commercial and financial journalism: The commodity price currents, exchange rate currents, and money currents of early modern Europe. Amsterdam, Netherlands: Nederlandsch Economisch-Historisch Archief.

[4] Posthumus, N. W. (1946). Inquiry into the history of prices in Holland. Leiden, Netherlands: E. J. Brill.

[5] Crouch \& Gray. (1774, July 30). South Carolina Price-Current. Retrieved from https://www.loc.gov/resource/rbpe.17200300/

[6] Chang, J. (2006). The road to ICIS Chemical Business (Americas). Chemical Market Reporter, 270(2), 6-7.

[7] IHS Markit. (2018). Chemical Economics Handbook (CEH). Retrieved from https://ihsmarkit.com/products/chemical-economics-handbooks.html

[8] Maizell, R. E. (1998). How to find chemical information: A guide for practicing chemists, educators, and students (3rd ed.). New York: John Wiley \& Sons.

[9] ICIS. (2018). About us. Retrieved from https://www.icis.com/about/

[10] Johnson, O. (2018). The price reporters: A guide to PRAs and commodity benchmarks. Abingdon, UK: Routledge.

[11] Spectrum Chemical. (2017). Chemicals. Retrieved from https://www.spectrumchemical.com/OA_HTML/Chemicals.jsp?minisite=10020 \&respid $=22372$

[12] Raizada, T. (2017). MEG. ICIS Chemical Business, 291(26), 32.

[13] Lord, C. (2000). Guide to information sources in engineering. Englewood, CO: Libraries Unlimited.

[14] Osif, B. A. (2012). Using the engineering literature. Boca Raton: CRC Press.

[15] Reichardt, R. (2005). A brief guide to finding chemical and petroleum prices and other statistical information. SLA Chemistry Newsletter, 19(4), 4-5.

[16] Peters, M. S., Timmerhaus, K. D., \& West, R. (2003). Plant design and economics for chemical engineers (5th ed.). New York, NY: McGraw-Hill.

[17] Reed Business Information strengthens portfolio with Schnell Publishing buy. (2000). Chemical Market Reporter, 257(12), 1.

[18] IHS Markit. (2010). IHS acquires chemical and energy products from Access Intelligence LLC. Retrieved from http://news.ihsmarkit.com/press-release/corporate-financial/ihsacquires-chemical-and-energy-products-access-intelligence-llc

[19] Reichardt, R. (2005). Bonehead move of the year: Chemical Market Reporter stops including chemical prices in its issues. $S T L Q$. Retrieved from http://stlq.info/2005/04/bonehead_move_of_the_year_chem.html

[20] ICIS. (2017). Indicative chemical prices a-z. Retrieved from https://www.icis.com/chemicals/channel-info-chemicals-a-z/

[21] U.S. Bureau of Labor Statistics. (2018). Producer price indexes. Retrieved from https://www.bls.gov/ppi/

[22] Federal Reserve Bank of St. Louis. (2017). Commodities. https://fred.stlouisfed.org/categories/32217

[23] El-Halwagi, M. (2017). Sustainable design through process integration (2nd ed.). Amsterdam, Netherlands: Elsevier.

[24] Ghaphery, J., \& White, E. (2012). Library use of web-based research guides. Information Technology and Libraries, 31(1), 21-31. 
[25] Krippendorff, K. (2013). Content analysis: An introduction to its methodology (3rd ed.). Los Angeles: Sage.

[26] Osorio, N. L. (2014). Content analysis of engineering LibGuides. 2014 ASEE Annual Conference \& Exposition, Indianapolis, Indiana June 15, 2014. https://peer.asee.org/20209

[27] Osorio, N. L. (2015). Electrical engineering reference resources: A survey from LibGuides. Collection Building, 34(1), 6-12.

[28] Chen, Y., \& Chen, X. (2015). Web-based subject guides for East Asian studies: Current status, challenges, and recommendations. Internet Reference Services Quarterly, 20(1-2), $1-17$.

[29] Dougherty, K. (2013). Getting to the core of geology LibGuides. Science \& Technology Libraries, 32(2), 145-159.

[30] Dougherty, K. (2013). The direction of geography LibGuides. Journal of Map \& Geography Libraries, 9(3), 259-275.

[31] Horton, J. J. (2017). An analysis of academic library 3D printing LibGuides. Internet Reference Services Quarterly, 22(2-3), 123-131.

[32] Stankus, T., \& Parker, M. A. (2012). The anatomy of nursing LibGuides. Science \& Technology Libraries, 31(2), 242-255.

[33] van Dyk, G. (2015). Finding religion: An analysis of theology LibGuides. Theological Librarianship, 8(2), 37-45

[34] American Institute of Chemical Engineers. (2017). Choosing a college/university for chemical engineering. Retrieved from https://www.aiche.org/community/students/abetaccredited-universities

[35] ForeSoft Corporation. (2017). TeamDesk. Retrieved from https://www.teamdesk.net/

[36] Texas A\&M University Libraries. (2018). Chemical engineering. Retrieved from http://tamu.libguides.com/chemicalengineering 
Appendix A: Chemical Pricing Sources on Library Research Guides

\begin{tabular}{|c|c|c|}
\hline Resource Name & Resource Type & Count \\
\hline ICIS Chemical Business & Trade Magazine & 29 \\
\hline ICIS Indicative Chemical Prices A-Z & Website - Commercial & 29 \\
\hline SciFinder & Database - Science/Engineering & 26 \\
\hline Sigma-Aldrich & Vendor Catalog & 24 \\
\hline Chemical Week & Trade Magazine & 19 \\
\hline Business Source Complete & Database - Business & 16 \\
\hline Chemical \& Engineering News & Trade Magazine & 13 \\
\hline USGS National Minerals Information Center & Website - Government & 12 \\
\hline Kirk-Othmer Encyclopedia of Chemical Technology & Monograph/Encyclopedia & 11 \\
\hline U.S. Energy Information Administration & Website - Government & 10 \\
\hline Factiva & Database - Business & 9 \\
\hline Chemical Profiles/ICIS Chemical Business (U of Texas) & Website - Library Chem Pricing & 9 \\
\hline Chem Sources & Buyer's Guide & 8 \\
\hline ChemExper.com & Website - Product Directory & 8 \\
\hline Chemical Engineering & Trade Magazine & 8 \\
\hline ICIS Website & Website - Commercial & 8 \\
\hline LexisNexis Academic & Database - News & 8 \\
\hline ThomasNet & Website - Product Directory & 8 \\
\hline Ullmann's Encyclopedia of Industrial Chemistry & Monograph/Encyclopedia & 8 \\
\hline Chemical Market Reporter & Trade Magazine & 7 \\
\hline ICIS for Students & Website - Commercial & 6 \\
\hline Reaxys & Database - Science/Engineering & 6 \\
\hline ABI/INFORM & Database - Business & 5 \\
\hline Cornell Chemical Pricing Guide & Website - Library Chem Pricing & 5 \\
\hline eMolecules & Website - Product Directory & 5 \\
\hline Fisher Scientific & Vendor Catalog & 5 \\
\hline OPD Chemical Buyers Directory & Buyer's Guide & 5 \\
\hline UT Chemical Economics Guide & Website - Library Chem Pricing & 5 \\
\hline Alpha-Aesar & Vendor Catalog & 4 \\
\hline BuyersGuideChem & Website - Product Directory & 4 \\
\hline Chemical Register & Website - Product Directory & 4 \\
\hline Chemical Week's Buyers Guide & Buyer's Guide & 4 \\
\hline ChemIndustry.com & Website - Product Directory & 4 \\
\hline Google & Other [Search Engine] & 4 \\
\hline ICIS Pricing (Website) & Website - Commercial & 4 \\
\hline Oil \& Gas Journal & Trade Magazine & 4 \\
\hline Producer Price Indexes (Bureau of Labor Statistics) & Website - Government & 4 \\
\hline
\end{tabular}




\begin{tabular}{|c|c|c|}
\hline TAMU Chemical Pricing Guide & Website - Library Chem Pricing & 4 \\
\hline Plastics Today/Plastics Exchange & Website - Commercial & $\overline{4}$ \\
\hline BCC Research & Database - Business & 3 \\
\hline Bloomberg & Database - Business & 3 \\
\hline ChemNavigator & Website - Product Directory & 3 \\
\hline CRB Commodity Yearbook & Monograph/Encyclopedia & 3 \\
\hline Datastream & Database - Business & 3 \\
\hline Basic Petroleum Data Book & Monograph/Encyclopedia & 2 \\
\hline Business Insights: Essential & Database - Business & 2 \\
\hline Chem.com & Website - Product Directory & 2 \\
\hline Chemical Economics Handbook & Monograph/Encyclopedia & 2 \\
\hline Chemical Engineering Buyer's Guide & Buyer's Guide & 2 \\
\hline Chicago Mercantile Exchange & Website - Commercial & 2 \\
\hline Dow Press Releases & Website - Commercial & 2 \\
\hline Engineering News-Record (ENR) & Trade Magazine & 2 \\
\hline ICIS Chemical Business Europe/Middle East/Asia & Trade Magazine & 2 \\
\hline Locally Stored Files from Various Sources & Other [Local Content] & 2 \\
\hline London Metal Exchange & Website - Commercial & 2 \\
\hline MarketResearch.com Academic & Database - Business & 2 \\
\hline Medicare Drug Pricing & Website - Government & 2 \\
\hline Oil, Paint, and Drug Reporter & Trade Magazine & 2 \\
\hline ProQuest Research Library & Database - General & 2 \\
\hline R \& D Chemicals & Website - Product Directory & 2 \\
\hline U.S. Industry Quarterly Review - Chemicals & Trade Magazine & 2 \\
\hline USDA Agricultural Prices Summary & Website - Government & 2 \\
\hline USDA Economic Research Service & Website - Government & 2 \\
\hline Wikipedia & Website - Nonprofit & 2 \\
\hline ABI/INFORM Trade \& Industry & Database - Business & 1 \\
\hline Academic Search Complete & Database - General & 1 \\
\hline Access World News & Database - News & 1 \\
\hline ACS Chemical Industries Buyers' Guide & Website - Product Directory & 1 \\
\hline Applied Science \& Technology Source & Database - Science/Engineering & 1 \\
\hline Bloomberg Precious and Industrial Metals & Website - Commercial & 1 \\
\hline Bureau of Labor Statistics & Website - Government & 1 \\
\hline Burlington Northern Sante Fe Railroad & Website - Commercial & 1 \\
\hline Business Insights: Global & Database - Business & 1 \\
\hline Canadian Business \& Current Affairs (CBCA) Database & Database - Business & 1 \\
\hline Canadian Newsstand Complete & Database - News & 1 \\
\hline CEIC Data (https://www.ceicdata.com/en) & Database - Business & 1 \\
\hline Chembargins.com & Website - Product Directory & 1 \\
\hline
\end{tabular}




\begin{tabular}{|c|c|c|}
\hline ChemBuyersGuide.com & Website - Product Directory & 1 \\
\hline ChemExpo, A Virtual Trade show & Website - Product Directory & 1 \\
\hline Chemical and Drug Suppliers [www.pharmweb.net] & Website - Product Directory & 1 \\
\hline Chemical Business (Bombay) & Trade Magazine & 1 \\
\hline Chemical Data Access Tool (CDAT) & Database - Government & 1 \\
\hline Chemical Marketing Reporter & Trade Magazine & 1 \\
\hline Chemical Online & Website - Product Directory & 1 \\
\hline Chemical Pricing Patterns & Monograph/Encyclopedia & 1 \\
\hline Chemical Week Charts (TAMU) & Website - Library Chem Pricing & 1 \\
\hline ChemicalBook & Website - Product Directory & 1 \\
\hline Chemicalland21 & Website - Commercial & 1 \\
\hline Chemistry and Industry & Trade Magazine & 1 \\
\hline City Chemical LLC & Vendor Catalog & 1 \\
\hline Clarkson University (Oxygen) & Website -Educational & 1 \\
\hline Commodity Prices & Monograph/Encyclopedia & 1 \\
\hline Directory of Chemical Producers & Monograph/Encyclopedia & 1 \\
\hline Engineering360 [Supplier Catalogs] & Website - Product Directory & 1 \\
\hline European Business (ProQuest) & Database - Business & 1 \\
\hline Financial Times Archives & Newspaper - Business & 1 \\
\hline Financial Times Commodities & Newspaper - Business & 1 \\
\hline FRED - Federal Reserve of St. Louis [Chemical PPIs] & Website - Government & 1 \\
\hline Frost \& Sullivan & Database - Business & 1 \\
\hline Hoovers Online & Database - Business & 1 \\
\hline Hydrocarbon Processing & Trade Magazine & 1 \\
\hline IBISWorld Industry Market Research Reports & Database - Business & 1 \\
\hline ICIS Americas Chemicals Outlook 2016 & Website - Commercial & 1 \\
\hline ICIS Chemical News & Website - Commercial & 1 \\
\hline ICIS Commodity \& Product Finder & Website - Commercial & 1 \\
\hline IHS Chemicals (Webpage) & Website - Commercial & 1 \\
\hline IHS Website & Website - Commercial & $\overline{1}$ \\
\hline InfoMine - CommodityMine & Website - Commercial & 1 \\
\hline International Drug Price Indicator Guide & Website - Nonprofit & 1 \\
\hline International Medical Products Price Guide & Website - Nonprofit & 1 \\
\hline International Pharmaceutical Abstracts & Database - Science/Engineering & 1 \\
\hline Intratec IC & Website - Commercial & 1 \\
\hline Inventory Update Reporting (IUR) US EPA & Website - Government & 1 \\
\hline LookChem & Website - Product Directory & 1 \\
\hline MarketLine Advantage & Database - Business & 1 \\
\hline Materials Science \& Engineering Database & Database - Science/Engineering & 1 \\
\hline Methanex, Incorporated & Website - Commercial & 1 \\
\hline
\end{tabular}




\begin{tabular}{|l|l|c|}
\hline Methanol Market Report & Website - Commercial & 1 \\
\hline NC State Chemical Pricing Guide & Website - Library Chem Pricing & 1 \\
\hline Oil Price Information Service (OPIS) & Website - Commercial & 1 \\
\hline OmniFile Full Text Select & Database - Business & 1 \\
\hline Pfaltz and Bauer & Vendor Catalog & 1 \\
\hline Pharmaceutical News Index & Database - Science/Engineering & 1 \\
\hline Plastics Technology (Company) & Website - Commercial & 1 \\
\hline Pressure Chemical (Company) & Website - Commercial & 1 \\
\hline Process Engineering & Trade Magazine & 1 \\
\hline Process Register: the Online Industrial Buyer's Guide & Website - Product Directory & 1 \\
\hline ProQuest Newsstand & Database - News & 1 \\
\hline Resin Pricing (Plastics Technology Website) & Website - Commercial & 1 \\
\hline ScienceLab & Website - Product Directory & 1 \\
\hline Specialty Chemicals Source Book & Monograph/Encyclopedia & 1 \\
\hline Strem Chemicals & Vendor Catalog & 1 \\
\hline TCI America & Vendor Catalog & 1 \\
\hline Trade DataWeb (U. S. International Trade Commission) & Database - Government & 1 \\
\hline UC Berkeley Chemical Pricing Guide & Website - Library Chem Pricing & 1 \\
\hline UCSD Chemical Pricing Guide & Website - Library Chem Pricing & 1 \\
\hline UL IDES Prospector Materials Database & Database - Science/Engineering & 1 \\
\hline UN Comtrade & Other [Website - Intergov.] & 1 \\
\hline US Census Bureau: Current Industrial Reports & Website - Government & 1 \\
\hline USDA NASS Quick Stats & Website - Government & 1 \\
\hline
\end{tabular}

